\title{
TCOM \\ Societal problem solver or deficient discipline? The debate about social science in the online public sphere
}

\section{Brigitte Huber, Irmgard Wetzstein and Ingrid Aichberger}

\begin{abstract}
This study uses the online discourse surrounding an Austrian publicly-funded study about "Islamic kindergartens" as a case study to approach communication about the social sciences in the online public sphere. Results from a discourse analysis of 937 user comments in online forums of two Austrian daily newspapers show that the social sciences are often referred to as a "special case". While some use this argument to neglect its societal relevance, others use it to highlight its role as societal problem solver. Moreover, users discuss characteristics of "true" social scientists and scrutinise the independence of institutionalised social science.
\end{abstract}

Keywords

DOI

Introduction
Public perception of science and technology; Science and media; Science and policy-making

https://doi.org/10.22323/2.18020204

Submitted: 9th July 2018

Accepted: 22nd January 2019

Published: 25th February 2019
Scientific knowledge and academic expertise are central to today's knowledge society [Stehr and Grundmann, 2010]. They are key resources for political actors to inform and legitimate political decisions [Bogner and Torgersen, 2005]. When engaging in political advising processes, researchers are caught between the rules of the scientific and the political systems [Lange and Marquardt, 2014]. One main challenge for social scientists when doing contract research is maintaining the scientific independence while cooperating with the contractee [Döring and Bortz, 2016]. As debates around the politicisation of science suggest, this is not always easy: "Political advocates will always look to science as a source of authority in support of their agendas" [Pielke, 2004, p. 415]. When scientific evidence is used selectively to support certain political agendas, it might contribute to the public perception of scientific work as being coloured by political values and beliefs [Bolsen, Druckman and Cook, 2013].

A contract study that was surrounded by such discussions is the publicly-funded qualitative study about "Islamic kindergartens" in Vienna, Austria. The 
study was performed by Prof. Ednan Aslan, Head of the Department of Islamic Religious Education at the University of Vienna, and funded by the Austrian Federal Ministry for Europe, Integration and Foreign Affairs (BMEIA). Based on excerpts from a leaked document, the editor-in-chief at the Austrian weekly newspaper "Falter", Florian Klenk, published an article about formal and - more importantly - content-related manipulations of the study, accusing officials of the BMEIA of making text changes aiming to attune the results to the right-wing Islam-sceptical governmental agenda. Subsequently, various Austrian and foreign media covered the alleged manipulation. Sebastian Kurz, then integration minister and now chancellor of Austria, and study author Ednan Aslan dismissed the accusations, the University of Vienna announced an examination into the study, and numerous actors from politics and science criticised the subsequent amendments conducted by the public client as well as the scientific character of the study.

This paper focuses on the online discourse linked to this case. The case of the "Kindergarten-Studie" triggered an intensive and controversial debate in online forums of various daily newspapers about the social sciences as an academic discipline. We are using this case to investigate communication about the social sciences in the online public sphere. More specifically, user comments on online news sites can be identified as a specific form of public arena, namely the "mass-media-induced discussion arena" [Lörcher and Taddicken, 2017, p. 5]. As Lörcher and Taddicken [2017] show, discussions about scientific topics in mass-media-induced discussion arenas differ from those in mass media arenas in terms of topic diversity and interpretations. While there is little detailed knowledge on the communication about the social sciences in the mass media arena [Schäfer, 2012; Scheu and Volpers, 2017], even less is known about mass-media-induced discussions on the social sciences. This is where our study comes in. We use the discourse surrounding the "Kindergarten-Studie" in online forums of Austrian daily newspapers "Der Standard" and "Die Presse" to investigate mass-media induced communication about the social sciences. We do so by conducting a discourse analysis based on the sociology of knowledge approach [Keller, 2005].

In literature, the public sphere is described as a network for communicating opinions [Habermas, 1992] or as a forum with different arenas where public actors speak in front of an audience [Neidhardt, 1994]. Gerhards and Neidhardt [1991] distinguish three different levels within the public sphere: (1) the encounter public sphere (e.g., communication on the street); (2) public events; and (3) mass media. While in the encounter public sphere, communication happens spontaneously, and people switch between the roles of being an actor and being the audience, in public events and especially in mass media the roles are fixed. With the emergence of the Internet, the public sphere has changed as "the structure of internet communication is fundamentally different from that of the old media - one in which gatekeeping journalists and mass media institutions seem to play a less important role" [Gerhards and Schäfer, 2010, p. 145]. In the online public sphere, four arenas can be distinguished [Schmidt, 2013]: (1) Mass media arena (e.g., online news sites); (2) expert arena (e.g., scientific journals); (3) arena of the collaborative public (e.g., Wikipedia); and (4) arena of the individual/personal public sphere (e.g., Facebook). While for the mass media arena and the expert arena the barriers to communication are high, the opposite is true for the latter one. Lörcher and Taddicken [2017] have expanded this concept by adding an additional arena with low communication 
barriers: (5) the discussion arena where lay people can exchange their views and opinions. While there is a growing body of research devoted to investigating communication about the social sciences in the mass media arena (see next section), there is a need for investigating the discussion arena. A very common form of this specific arena is the mass-media-induced discussion arena [Lörcher and Taddicken, 2017], i.e. user comments on online news sites. But why is it relevant to look at this specific arena? Research has identified differences in how discussions in these arenas evolve. For example, a content analysis of the climate change communication in different German online public arenas has identified a higher diversity of topics and interpretations in the mass-media induced discussion arena than in the journalistic or the expert arena [Lörcher and Taddicken, 2017].

Social science in the public sphere
While in the $18^{\text {th }}$ century, scientific disciplines as we know them today hardly existed, in the $19^{\text {th }}$ century science became increasingly specialised and the fragmentation process of science into disciplines and subdisciplines is still going on [Schummer, 2008]. The specialisation and fragmentation of science are functional as different types of knowledge are needed in society. The natural sciences mainly produce knowledge aimed at controlling nature; the social sciences and humanities provide knowledge in terms of interpreting the world and allowing for orientation [Stehr, 1994]. However, the boundaries are blurry. "Scientific communities have increased dramatically, developing into ever-growing networks that cross institutional, geographical, and disciplinary barriers" [Declich and d'Andrea, 2005]. Novel arrangements form between natural and social scientists, and "social scientists are becoming a required component of research programmes" [Calvert and Martin, 2009]. Social scientists are involved in a wide range of roles in public engagement with science and technology agendas [Wilkinson, 2014], for example as advisers or evaluators [Jung, 2009]. While non-academic actors perceive the role of the social sciences as an instrumental problem-solving discipline whose objectives are defined by others, academic social scientists see the social sciences as intellectually independent [Burchell, 2009]. Recent research shows the manifold impact academic social scientists have in society today which ranges from business and government to civil society sectors [Bastow, Dunleavy and Tinkler, 2014]. However, the societal relevance of the social sciences has consistently been under debate for several decades. For example, more than 40 years ago, Nowotny [1975] discussed the "societal irrelevance" of the social sciences and argued that the social sciences were still not seen as being equally relevant in society compared to the natural sciences. More recently, Felt [2000] stated that the social sciences, on the one hand, are of high importance for society, but still often remain invisible because they are often just implicitly referred to in the public discourse. In the following, we start by presenting the state of research on the communication about the social sciences in the mass media arena in terms of media coverage of the social sciences. Then we focus specifically on the mass-media-induced discussion arena, and provide information on the case of "Islamic kindergartens" in Vienna.

\section{Social science in the mass media arena}

Research shows that science journalists are well aware that they do not cover the social sciences that often [Bauer et al., 2013]. This aligns with content-analytical results suggesting that the social sciences appear less often on the journalistic 
agenda than the natural sciences [Böhme-Dürr, 1992; Göpfert and Schanne, 1998; Kaltenbrunner et al., 2006]. However, research also reveals that the social sciences are not exclusively placed in the science sections. For example, Brantner and Huber [2013] show that communication studies are rarely covered in the science sections of Austrian quality newspapers, but rather in the political, media, and cultural sections. Hence, when using a broad definition of science coverage, the social sciences are substantially visible, while when following a narrow definition of science coverage, the social sciences remain rather invisible [see Summ and Volpers, 2016; Scheu and Volpers, 2017]. Regarding the visibility of the social sciences in the news coverage, differences by country are observable as well. While in Denmark the social sciences come in second in science coverage [Vestergård and Nielsen, 2017], they come in last in the U.K. [Vestergård and Nielsen, 2016] and are midrange in Croatia [Šuljok and Vuković, 2013]. While in Danish newspapers political triggers initiated coverage more often, scientific journals were an important trigger in the U.K. [Vestergård and Nielsen, 2017; Šuljok and Vuković, 2013]. So, the "problem" might not necessarily be the amount of media coverage about the social sciences. Instead, the way it is reported might make the difference. Indeed, Knudsen's [2017] frame analysis of the humanities in Danish print news media shows that three quarters of the articles frame the humanities as deficient in the sense of an irrelevant, neglected, stagnant, or deformed discipline. Accordingly, we are interested to see whether the social sciences - which are often lumped into one category with the humanities - are discussed as a deficient discipline and delegitimised within the online discourse. Finally, recent research also highlights the different roles of the social scientists particularly in crisis coverage [Fähnrich and Lüthje, 2017], where social scientists tend to be presented as "public intellectuals" who provide general assessments and commentaries rather than as "objective experts" who explain phenomena based on research results. Other roles of social scientists in the media have been identified as well, such as the "alleged expert" who has only limited expertise and therefore explains phenomena by presenting subjective opinion, the "politicized intellectual" who is presented to be guided by subjective interests and political positions, and the "pseudo-intellectual" who is assumed to have a lack of persuasive power and denied the analytical skills to interpret the phenomenon. Hence, the question arises which roles can be identified for social scientists in user discussions in the mass-media-induced public sphere. To the best of the author's knowledge, there are no empirical findings to date on the communication about the social sciences in the mass-media-induced discussion arena. For this reason, we are going to draw on studies dealing with user comments in other thematic contexts.

Mass-mediainduced discussion arena
The mass-media-induced discussion arena can be described as an arena with "low barriers to communicate dialogically to an audience that has not been further specified" [Lörcher and Taddicken, 2017]. Starting from journalistic input in the form of news articles, users discuss topics more or less related to news stories with other users. Communication scholars are increasingly interested in investigating user comments as they have been found to affect not only personal opinion and attitudes [e.g. Anderson et al., 2014; Hsueh, Yogeeswaran and Malinen, 2015], but also individuals' perception of the public opinion climate [e.g. Lee and Jang, 2010; von Sikorski and Hänelt, 2016]. Accordingly, user comments dealing with the social sciences have the potential to influence other users' attitudes toward the social science as well as their public opinion perceptions regarding the social 
sciences. Thus, analysing the content of these comments is highly relevant for communication research. However, user comments are also deemed problematic because discussions in online public spheres are not always as civil as one would hope from a normative perspective. For example, in 2013 the magazine Popular Science decided to shut down its user comments [LaBarre, 2013]. The decision was made based on empirical findings suggesting that uncivil user comments on scientific topics not only polarised readers, but they also changed how individuals interpreted the news story itself [Anderson et al., 2014]. Research shows that around $20 \%$ to $40 \%$ of user comments on news stories consist of uncivil comments [Coe, Kenski and Rains, 2014; Rowe, 2015; Santana, 2013; Su et al., 2018]. Hence, the user comments in our case study might also entail a certain degree of incivility - targeting for example other users and social scientists. Research on the public perception of science suggests that people might have some reservations regarding the social sciences. For example, in the U.S., only half of the population thinks that the social sciences are actually scientific [Science and Engineering Indicators, 2014]. Similarly, surveys in the U.K. and Switzerland show that only a few people associate the social sciences with the term science whereas science was most commonly referred to as being medicine, biology, chemistry, and physics [IPSOS, 2014; Wissenschaftsbarometer Schweiz, 2016; see also Schäfer et al., 2018]. Yet, people are quite interested in the social sciences. Results of a survey of 1,007 people in Germany show that the gap between the natural sciences and the social sciences is not that big in this regard. More specifically, $58 \%$ of respondents are interested in the natural sciences, and $42 \%$ of respondents show an interest in disciplines related to the social sciences [Wissenschaftsbarometer - Wissenschaft im Dialog, 2017].

\section{The case of "Islamic kindergartens" in Vienna}

In the following, we present information on Islamic kindergartens and media representation of Islam to further contextualise the case study. There are no official statistics regarding the number of Islamic kindergartens in Vienna. When reading the contract study on Islamic kindergartens in Vienna, ${ }^{1}$ it becomes obvious that even just identifying Islamic kindergartens as such is difficult. While Catholic kindergartens often label themselves as Catholic, this is not true for Islamic kindergartens. The authors of the contract study about so-called "Islamic kindergartens" estimate that there are around 150 Islamic kindergartens in Vienna. Islamic kindergartens became front and centre in public debate because Sebastian Kurz used it as campaign issue by stating that there should be no Islamic kindergartens in Vienna. ${ }^{2}$ That fits well into the dominant negative portrayal of Islam in the media. For example, Muslims are often included in stories on violence, terrorism, and illegal immigration [Mishra, 2007], and portrayed as fanatic, irrational, and violent oppressors of women [Ibrahim, 2010]. Indeed, a meta-analysis of 345 published studies between 2000 to 2015 show that Muslims tend to be negatively framed in media coverage, and Islam is dominantly portrayed as a violent religion [Ahmed and Matthes, 2017].

\footnotetext{
1 “Evaluierung ausgewählter Islamischer Kindergärten und -gruppen in Wien [Evaluation of selected Islamic kindergartens and groups in Vienna]" https:/ /www.bmeia.gv.at/fileadmin/ user_upload/Zentrale/Integration/Studien/Abschlussbericht_Vorstudie_Islamische_ Kindergarten_Wien_final.pdf.

${ }^{2}$ https: / / kurier.at/politik/inland/sebastian-kurz-im-kurier-gespraech-islamische-kindergaertenabschaffen/271.008.503.
} 
The study uses a sociology of knowledge approach to discourse [SKAD], a research programme developed by Keller [2001]. It is embedded in the sociology of knowledge tradition and aims to investigate the discursive construction of symbolic orders [Keller, 2011]. SKAD builds on Berger and Luckmann's [1966] work on the social construction of reality and uses Foucault's concept of discourse referring to power practices [Foucault, 1988]. Its concept of knowledge is broad, referring "to everything which is supposed to 'exist' (including ideas, theories, everyday assumptions, language, incorporated routines and practices)" [Keller, 2005 , p. 3]. SKAD serves as an appropriate research approach for this study, because it has more of a sociological as opposed to a linguistical focus and addresses the discursive construction of reality as an empirical (material) process [Keller, 2005].

\section{Research questions}

This study aims at structuring the public online discourse surrounding the manipulation allegations by identifying thematic aspects and arguments. The study wants to reveal underlying narratives, frames, and societal knowledge repertoires about the social sciences as an academic discipline or profession. For this purpose, in keeping with the principles of the sociology of knowledge approach to discourse [Keller, 2005; Keller, 2011; Keller, 2013], and considering the state of research as described above, we pose the following research questions:

- How is the discourse surrounding the "Kindergarten-Studie" organised with regard to individual discourse threads?

- Which topics and arguments are discussed?

- How are the social sciences and how are social scientists legitimised and/or delegitimised within the discourse?

- Which knowledge do participants in the discourse share about the social sciences/social scientists especially in the context to perceived professional and societal roles as well as to scientific quality?

\section{Analysis corpus}

To answer these research questions, we conducted a discourse analysis based on the sociology of knowledge approach [Keller, 2005]. We examined online user comments, which were posted in the online forums of two Austrian newspapers, "Der Standard" and "Die Presse". They are the leading newspapers in the quality newspaper segment in Austria with a national coverage of $6.5 \%$ and $4.2 \%$ respectively [MA - Media Analyse, 2017]. According to their editorial policies, "Der Standard" 3 is left-liberal, and "Die Presse"4 is bourgeois-conservative [Magin and Stark, 2011]. The decision to focus on online forums from quality newspapers rather than on those from tabloid papers was based on the following

\footnotetext{
${ }^{3}$ https: / / derstandard.at/2000008949975/Blattlinie-standard.

${ }^{4}$ https: / / www.styria.com/de/die-presse-ein-intellektuelles-aushangeschild-734.
} 
considerations: (1) We expected postings to produce more discourse quality in terms of an exchange of arguments and a variety of topics and identifiable knowledge repertoires. (2) A first review showed far fewer comments referring to the "Kindergarten-Studie" in tabloid paper forums than in quality paper forums. For the composition of the analysis corpus we first conducted an archive search at http:/ / derstandard.at and http:/ / diepresse.com using the terms "Aslan", "Kindergarten-Studie" and "Islamstudie" from 4 July 2017 to 11 July 2017 (one week after the publication date of the "Falter" report). The search yielded 31 relevant journalistic articles: Fifteen at http:/ / diepresse.com and 16 at http://derstandard.at. Considering that articles might serve as agenda setters for the following user discussions and with the goal of covering as many topics and arguments as possible within the discourse, articles reporting on the same or very similar sub-topics or aspects were excluded. This resulted in the selection of six articles with different perspectives and actors from these search hits (see Table 1). For the sake of feasibility and to ensure that as many comments as possible would show clear reference to the "Kindergarten-Studie", the first (= oldest) 200 posts per article were then added to the final analysis corpus. The final analysis corpus consisted of 937 comments. The analysis process consisted of two parts: a descriptive part and a more interpretative part. We started by identifying topics in the discourse surrounding the study on "Islamic kindergartens" that are related to the social sciences, as well as references to other discourses (e.g., negative campaigning). In a next step, we assigned the different arguments to the identified topics. Overall, this procedure allowed us to reduce the text, structure the content, understand the story line of the discourse, and get an overview of dominant thematic aspects and argumentative patterns. The coding process was done using MAXQDA. In addition, each author took notes in a Word document. The coding process was conducted independently by each author and was accompanied by reflective talks and review loops. In the second, more interpretative part of the research process, building on the identified topics, arguments, and dominant thematic aspects, we then detected overall discourse patterns and underlying interpretative schemas and knowledge repertoires.

\section{Ethical considerations}

The online forums of the two Austrian daily newspapers "Der Standard" and "Die Presse" are publicly accessible, i.e. all readers of the online news stories can see the user comments related to the news stories; no membership is required. When analysing text that is publicly available on web forums for research purposes, some ethical challenges arise. According to Sugiura, Wiles and Pope [2017], getting informed consent is not really viable. Instead, the focus should be on guaranteeing anonymity and minimalizing potential risks for the research subjects. We considered replacing user names with "User A", "User B" etc., but decided against it as "verbatim quotes can often be traced back via search engines to the original website and hence to the forum member who made them" [Sugiura, Wiles and Pope, 2017, p. 194]. Fortunately, the forum users used pseudonyms rather than real names. Hence, the risks that our study might damage the users are very minimal. 
Table 1. Analysis corpus.

\begin{tabular}{|c|c|c|c|c|c|}
\hline Nr. & Date & Article & Newspaper & $\begin{array}{l}\text { Number } \\
\text { of Postings }\end{array}$ & $\begin{array}{l}\text { Number of } \\
\text { of Selected Postings }\end{array}$ \\
\hline 1 & July 5 & $\begin{array}{l}\text { Islamstudie unter Manipula- } \\
\text { tionsverdacht: Kritik an Kurz, } \\
\text { Uni prüft [Islam study under } \\
\text { suspicion of manipulation: } \\
\text { criticism of Kurz, University } \\
\text { examines] }\end{array}$ & Der Standard & 4612 & 200 \\
\hline 2 & July 5 & $\begin{array}{l}\text { Uni Wien prüft Kindergarten- } \\
\text { studie [University of Vienna ex- } \\
\text { amines kindergarten study] }\end{array}$ & Der Standard & 89 & 89 \\
\hline 3 & July 5 & $\begin{array}{l}\text { Studie umgeschrieben? Islam- } \\
\text { Theologe verteidigt Aslan } \\
\text { [Study rewritten? Islam theolo- } \\
\text { gian defends Aslan] }\end{array}$ & Die Presse & 188 & 188 \\
\hline 4 & July 5 & $\begin{array}{l}\text { Die Bauchgefühlsdemokratie } \\
\text { und die islamischen Kinder- } \\
\text { gärten. Leitartikel von Erich } \\
\text { Kocina [Gut feeling democracy } \\
\text { and Islamic kindergartens. } \\
\text { Editorial by Erich Kocina] }\end{array}$ & Die Presse & 60 & 60 \\
\hline 5 & July 6 & $\begin{array}{l}\text { Islam-Studie: "Hat mit } \\
\text { Forschung nichts zu tun" } \\
\text { (Interview Schaffar) [The Islam } \\
\text { study "has nothing to do with } \\
\text { research." (Interview Schaffar)] }\end{array}$ & Der Standard & 2576 & 200 \\
\hline 6 & July 8 & $\begin{array}{l}\text { Plagiatsforscher: Ednan Aslans } \\
\text { Doktorarbeit "unsauber" [Plagi- } \\
\text { arism researcher: Ednan Aslan's } \\
\text { dissertation "unclean"] }\end{array}$ & Der Standard & 2458 & 200 \\
\hline Total & & & & 9983 & 937 \\
\hline
\end{tabular}

We identified five dominant discourse threads ${ }^{5}$ manifested in various topics discussed in the context of the "Kindergarten-Studie". In the following, we give an overview of these discourse threads (see Table 2), go into more detail regarding corresponding arguments, and discuss the question of a possible underlying narrative and knowledge repertoires, referring to examples from the analysis corpus. ${ }^{6}$

\section{Discourse threads}

(1) One of the most prevalent discussion threads evolved around the question of how to evaluate the possible forgery and to what extent it constitutes a scandal. The discourse participants take opposing positions. Users who classify the possible manipulation of the "Kindergarten-Studie" as a scandal refer to the

\footnotetext{
${ }^{5}$ In addition, the discussion surrounding the "Kindergarten-Studie" also refers to other discussions and topics, such as a prior study of Prof. Aslan on Islamic kindergartens in Vienna in the year 2015, the plagiarism case of Guttenberg in Germany in 2011, the scandal around the illegal caregiver for former chancellor Wolfgang Schüssel's mother-in-law in the context of the election campaign 2006, and negative campaigning in general. Discussion participants in the forum of Die Presse also referred to the discussion taking place in the forum of Der Standard.

${ }^{6}$ We have translated sample user comments into English. For the German version, see appendix.
} 
instrumentalization of science, stating that for sure it is a scandal when politicians try to influence social scientific research according to their agenda. One user puts it as follows:

\begin{abstract}
"Don't you understand that this is a highly explosive topic? It is not about Islamic kindergarten or Kurz, the problem is commissioning a researcher who has no clue about social-scientific methodology, who brings discredit on the whole science, and the client manipulates the already unscientific study according to his political motives and presents it as thorough. This is propaganda and manipulation as its best. That should not be part of our politics. And the money for the study has vanished. They should have done a serious study, so they would be able to provide facts now." (stopBashing)
\end{abstract}

They also highlight the relevance of evidence-based policy and argue that a serious study would have been important as a solid basis for political decisions. Moreover, the aspect of wasting tax money enters the discussion, with participants referring to politicians using tax money to commission scientific research and then manipulating the results. Discourse participants on the con side, i.e., users who do not view the possible manipulation of the "Kindergarten-Studie" as a scandal, use the argument of not needing a study anyway, stating that studies of this kind are simply useless or that no one needs a study to see that Islamic kindergartens are problematic. Therefore, in their view it is irrelevant whether or not the study is manipulated. One user wrote: "It doesn't matter whether the study has been fudged, 'enhanced', or manipulated or does anyone want to tell me that everything is fine in Vienna?" (a.-s.) Discourse participants also argue that all kinds of contract research produce results confirming the agendas of the contracting parties, therefore they are not surprised by this possible manipulation and do not perceive it as a scandal.

(2) Another prominent discussion thread is linked to the question of what is actually (social-) scientific and what applies as (social-) scientific quality standards in general and especially with regard to contract research. In this thread, some discourse participants follow the "mission" to explain to other users what is means to work empirically. In the course of the discussion, a dichotomy is established between experts and lay people. More specifically, some discourse participants try to position themselves as experts by highlighting their own knowledge on social-scientific theories or methods and/or by emphasising the lack of knowledge of other users. In doing so, they use two different strategies. By using examples (for explaining sampling methods, research design, etc): "Scientific would be, for example, to send standardized questions to the kindergarten and analysing them afterwards." (Ich bin das Scheitern) A second strategy is to use metaphors (for making a distinction between non-scientific terms, like "gut instinct", "pseudo-science", or "stories", etc.). For example, one user argues: "I have also heard stories and form my opinion based on this. But that is something different, not a study!" (Lampenschirm) Users also discuss what a "real" social scientist looks like by using perspectives of academic rank and academic writing. For example, discourse participants delegitimise a social scientist because she is not a professor: "It's always nice when people without a Ph.D. (like Ms Schaffer) talk about the scientific nature of work. These people then supervise master theses, which makes the scientific spiral take a further downturn." (Rohnny Jotten) Also 
publishing in science blogs rather than solely in academic journals was used to delegitimise the social scientist. Quality criteria of social science is discussed, with discourse participants classifying social science as a special case that has to be especially rigorous in meeting quality criteria because the social sciences already have an image of not being "real" science.

\begin{abstract}
"If someone works scientifically unclean (and this is expressed politely), then this has to be criticized - regardless of the study's content. And there are certain standards (objectivity, reliability, and validity) that should be met. This is especially true for the social sciences - as they have the reputation of being arbitrary and 'not a real science'." (Allosaurus)
\end{abstract}

It is noteworthy that discussion participants generally switch between the social sciences and science as a whole when discussing characteristics and quality criteria.

(3) A less prominent discussion thread deals with the usefulness of the social sciences. Some discourse participants neglect any usefulness of the social sciences by arguing that all people need to identify important problems of today's society are sanity and reason as well as everyday observations. Another argument used to delegitimise the social sciences is again the argument of tax money, stating more sweepingly than in the first discussion thread that giving money to social scientists to conduct this kind of research is just a waste of tax money. Other discourse participants try to convince these users of the relevance of the social sciences by arguing that everyday observations are not at all sufficient to identify and understand societal problems.

(4) The independence of the social sciences is a fourth discussion thread. Discourse participants discuss the dependency of the social sciences in terms of political orientation. The sceptical view is dominant, and users speculate about the dimensions of partisanship and find it at different levels. Specifically, some blame the whole social sciences and the humanities for being partisan: "Humanities and social scientists are actually mainly left-leaning academics. Computer scientists are rather mixed!" (Rana). Others refer to specific disciplines:

\footnotetext{
"The University of Vienna and its departments are left-leaning (see e.g., gender studies, political sciences, etc.) and are political opponents of Kurz. You could also ask the Green Party or the Social Democrats to evaluate the study. I do not doubt for a second that the study is politically coloured to some extent. However, at the University of Vienna whole study programmes are so." (Ausgeflippter Lodenfreak)
} 


\begin{tabular}{|c|c|c|c|}
\hline 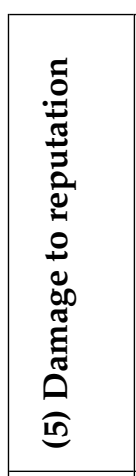 & 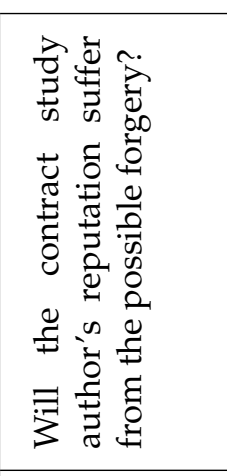 & 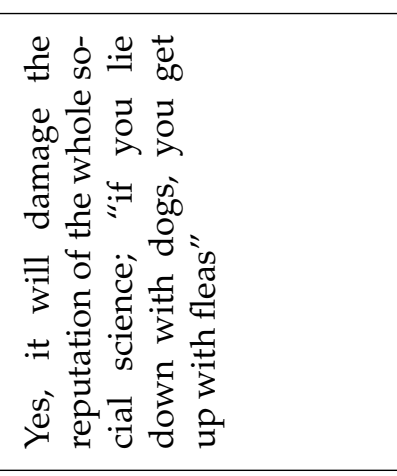 & 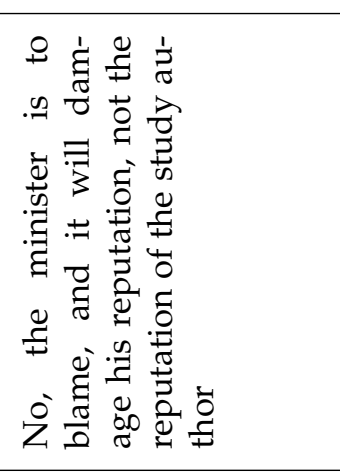 \\
\hline 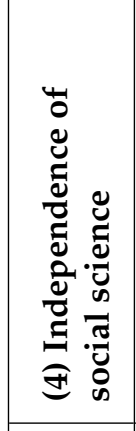 & 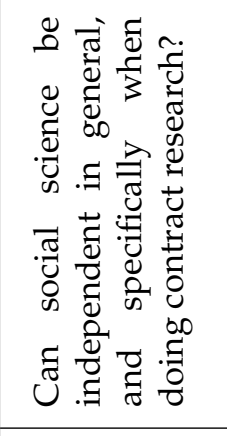 & 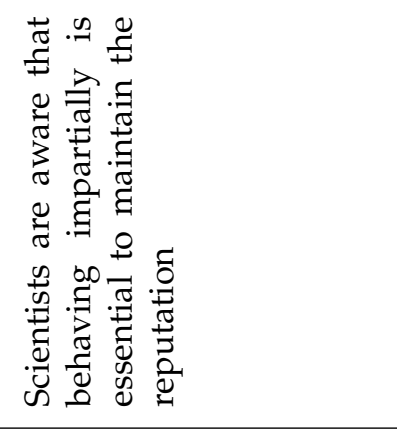 & 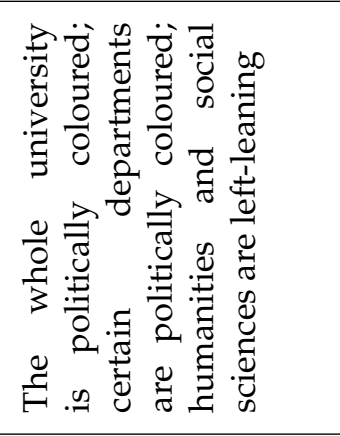 \\
\hline 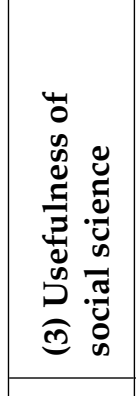 & 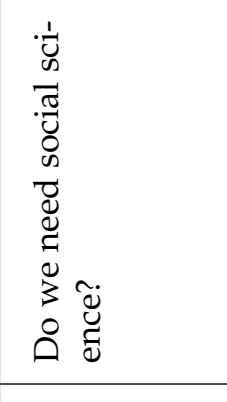 & 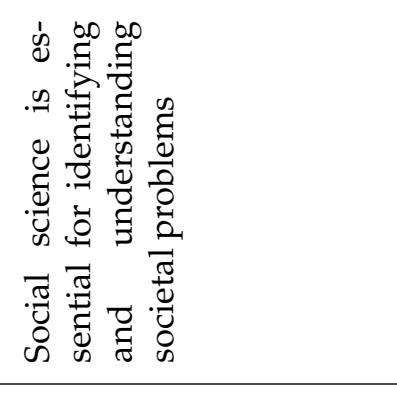 & 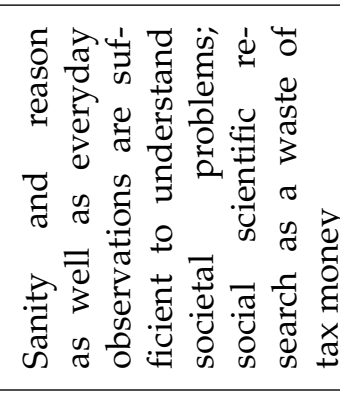 \\
\hline 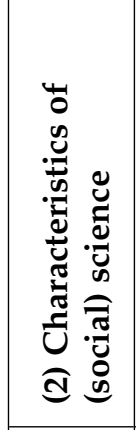 & 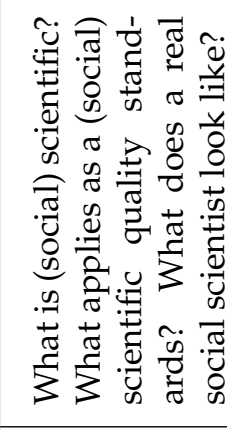 & 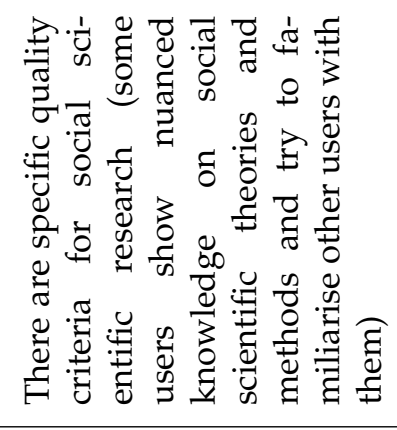 & 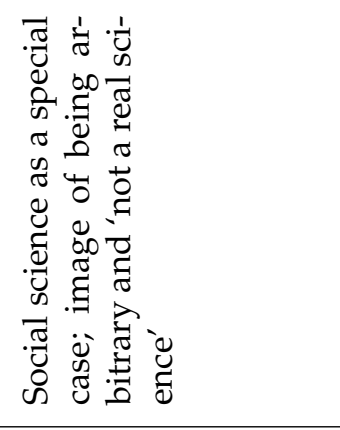 \\
\hline 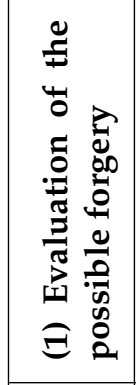 & 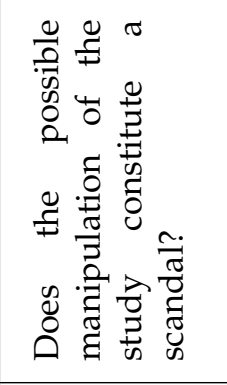 & 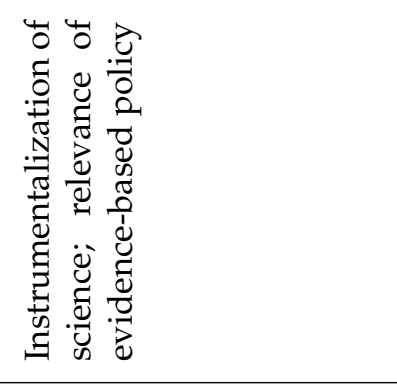 & 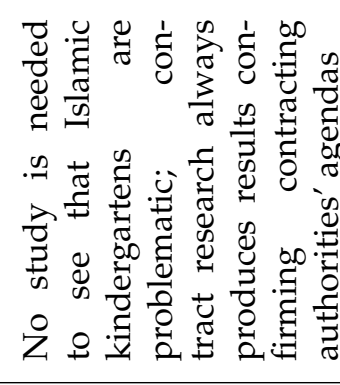 \\
\hline 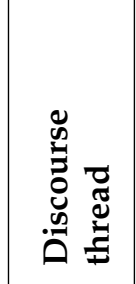 & 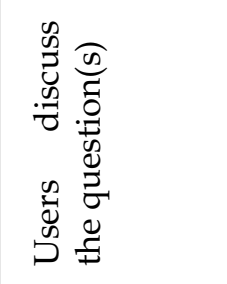 & 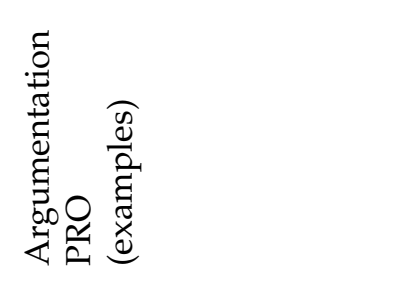 & 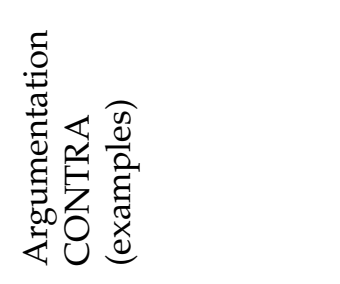 \\
\hline
\end{tabular}


By contrast, some users assume that the rectorate of the University of Vienna is connected to the conservative political party ÖVP and the law school to be right-wing leaning.

(5) The fifth discussion thread deals with the possible damage to the reputation of the study author and his institution. Some users clearly think Professor Aslan, the author of the contract study, failed: "The only one to blame is Aslan. Anyone who allows some ministry officials to edit a scientific study does not deserve any sympathy. If you lie down with dogs, you get up with fleas." (Dr Sheldon Lee Coper) One argument is that this misconduct might damage the reputation of the social sciences in general: "Whether or not the country has a problem with Islam has nothing to do with the fact that someone is damaging the reputation of science through his way of working." (criticalvoice) Others argue that Sebastian Kurz, as Minister for Foreign Affairs also responsible for migrant integration issues at that time, and his team are responsible for the misconduct which will therefore damage their reputation. Finally, some users also refer to methodological weaknesses of the study, and argue that one has to consider that Professor Aslan is working in the field of religious educational science: "Would like to protect Aslan as he is religious educationalist and not a pure social scientist. This method mix is definitely harder to handle." (witherabbitt)

By using the case of a contract study on "Islamic kindergartens" in Austria, the study at hand aimed to investigate communication about the social sciences in the online public sphere. The discourse analysis of 937 user comments in online forums of two Austrian daily newspapers shows that user comments on the social sciences are divided. While many discourse participants show a nuanced knowledge of social scientific theories and methods and try to familiarise other users with them, some participants refuse to acknowledge any relevance of social-scientific research by referring to everyday observations as being a sufficient indicator to identify and understand societal problems. The perception of a whole discipline as being irrelevant or deficient was also found for the humanities in the Danish media coverage. Knudsen [2017] summarises that while it is certainly problematic that media highlight the deficient character of the discipline rather than focusing on research results and knowledge from the field, readers may not always recognise the latter, even when they encounter it while reading the news. In literature, this problem has also been discussed for the social sciences [Saxer, 1997] and has to be seen in view of "the overlap between the expert knowledge of social science researchers and people's everyday experience of human existence" [Cassidy, 2008, p. 231]. Hence, social science expertise is not necessarily identifiable at first glance. Recently, the Faculty of Social Sciences at the University of Vienna launched a "Societal Impact Platform". 7 The aim of this initiative is to make the social sciences and its research and researchers publicly visible. Our findings suggest that the independence of the social sciences could be a relevant subject of discussion for this or similar initiatives as many discourse participants speculated about the partisanship of the social sciences as a whole or of specific disciplines. Moreover, contract research itself is a topic that invites speculation in terms of the independent character of science as some participants in the online discourse argue that this kind of research generally tends to indulge the clients. These findings

\footnotetext{
${ }^{7}$ For more details on the Societal Impact Platform, see https: / impact-sowi.univie.ac.at/ueber-uns /.
} 
clearly point toward a need for the social sciences and social scientists to reflect on their roles. Fähnrich and Lüthje [2017, p. 23] conclude that "the role of the public intellectual might fall victim to political interests and personal agendas". Especially political scientists are often seen as partisan when speaking as pundits in the news [Huber, 2014]. The extent to which this constitutes a problem regarding the image of the social sciences, is an open question for future research.

\section{Limitations and implications for future research}

These conclusions are limited in certain ways. First, user comments are only one form of public discussion and do not represent "the public" in general. For example, a recent study shows that only $14 \%$ of news users comment on the news, and compared to people who read news but do not comment, they tend to often be male, have lower levels of education, and have lower incomes [Stroud, Duyn and Peacock, 2016]. Secondly, when analysing user comments, information on discourse participants are limited. Only very few participants in the online discourse have identified themselves as social scientists by explicitly writing that they work in the field of social research. Hence, it is hard to say to what extent social scientists raised their voice in the analysed discourse. What is more, we assume that also paid users of political parties took part in the discussion. For example, one user posted repeatedly similar messages ("We don't need a study!"). Third, the analysed online comments might also deviate from the opinion of the general public due to the peculiarity of the topic. One should be aware that the case of "Islamic kindergartens" deals with a highly political and controversial topic (Islam). Hence, the debate surrounding this case may differ from other debates. On a positive note, it might be livelier and more interesting than other debates. However, one downside of choosing a highly political and controversial topic might be that users might discuss the social sciences in a less unbiased way than in other contexts. Moreover, the case deals with the possible manipulation of a scientific study. Hence, in terms of the public debate of the social sciences, the "Kindergarten-Studie" doubtlessly forms a special case also in this regard. It certainly triggers a discussion around bad practices of contractual social-scientific research rather than a comprehensive reflection on the discipline and its role in public discourse and for society as a whole. While it is difficult to generalise results beyond the case of "Islamic kindergartens" for this reason, future research can definitely connect to our study results, when, for example, elaborating on whether critical arguments challenging the social sciences or even scrutinising the legitimacy of the discipline are narratively reproduced in broader debates about the social sciences or in other cases dealing with better or even best social science practices. Fourth, the analysed corpus is quite narrow. While our decision to focus on the first (= oldest) 200 posts per article was important in terms of making the analysis feasible, it certainly resulted in an abbreviated and incomplete reconstruction of the discourse at hand. Hence, an analysis of all the user comments might have revealed some additional discussion threads containing further narrations on social science. Moreover, by focussing on Austrian quality newspapers, the study excluded conversations in other media outlets. Hence, further research on communication about the social sciences online in other thematic contexts could expand this direction by considering also online forums of other news sites, or by comparing different online public arenas (i.e., mass media arena, expert arena, mass-media-induced discussion arena), as suggested by Lörcher and Taddicken [2017]. 
In general, studying how people discuss the social sciences should be given more attention by communication researchers. Understanding what people think and know about the social sciences and which narratives are dominant in the public discourse about the social sciences will form our current understanding of the image, reputation, and societal relevance of the social sciences.

\section{Conclusions}

Despite these limitations, our study makes an important contribution to the emerging research on the roles of the social sciences in the public sphere by providing a solid starting point for future studies. The results of our discourse analysis of user comments in the forum of two Austrian daily newspapers suggest that the social sciences are still struggling to some extent with the image of not being as scientific as the natural sciences but, more importantly, they are faced with new challenges. How can the social sciences guarantee independence when doing contract research for political actors? Users participating in the online debate surrounding the "Kindergarten-Studie" have different perspectives on this, ranging from optimistic and highlighting the importance of social scientific expertise for society to arguing negatively that contract research per se can never be independent as such findings have to satisfy the client. Hence, social scientists might develop strategies to deal with the challenges arising from acting at the intersection of science and politics.

Acknowledgments We would like to thank the Faculty of Social Science at the University of Vienna for funding the proofreading of the manuscript.

Appendix A. User comments in the German version
1 "Verstehen sie denn nicht die brisanz des themas? Es geht hier nicht nur um die islamkindergärten und kurz, sondern darum, dass man eine studie in auftrag gibt an einen wissenschafter der keine ahnung von sozialwissenschaftlicher methodik hat, dieser im Prinzip die ordentlich arbeitende wissenschaft in verruf bringt und der auftraggeber zu seine politisch motivierten zwecke die ohnehin unwissenschaftliche Studie noch manipuliert und als voll ausgibt. Das ist Propaganda und manipulation vom feinsten. Sowas gehört nicht in unsere politik. Und das studiengeld ist futsch. Man hättr eine ordentliche Studie finanzieren konnen und stünde nun mit fakten da." (stopBashing)

2 "Ob die Studie gefälsch, "geschönt" oder manipuliert wurde ist eigentlich irrelevant oder will mir wer erklären, dass alles super ist in Wien?" (a.-s.)

3 "Wissenschaftlich wären z.b. Standardisierte Fragen, die man an die Kindergärten schickt und die man dann auswertet." (Ich bin das Scheitern)

4 "Ich kenn vom Hörensagen auch einzelne Geschichten und bilde mir damit meine Meinung. Aber das ist eben was Anderes als eine Studie!" (Lampenschirm)

5 "Ich finde es immer schön, wenn nicht-promovierte Menschen (wie Frau Schaffar) über die Wissenschaftlichkeit von Arbeiten sprechen. Diese betreuen dann offensichtlich Diplomarbeiten, wodurch sich die wissenschaftliche Spirale weiter nach unten dreht." (Rohnny Jotten) 
6 "Wenn jemand wissenschaftlich nicht sauber (und das ist an dieser Stelle noch höflich ausgedrückt) gearbeitet hat, dann ist das zu kritisieren — unabhängig vom Inhalt der Studie. Und es gibt nun Mal Standards (Objektivität, Reliabilität und Validität) die es einzuhalten gibt. Und gerade bei den Sozialwissenschaften ist das heikel — haben sie doch den Ruf beliebig und ,keine richtige Wissenschaft' zu sein!" (Allosaurus)

7 "also Geistes- und Sozialwissenschafter sind tatsächlich hauptsächlich eher linksorientierte Akademiker. Informatiker werden durchmischt sein!" (Rana)

8 "Die Uni Wien und ihre Institute stehen selbst links außen (siehe z.B. Gender, Politikwissenschaften, usw.) und sind politische Gegner von Kurz. Da kann man gleich die Grünen oder die SPÖ die Studie untersuchen lassen. Ich bezweifle keine Sekunde dass die Untersuchung zu den Kindergärten ein wenig politisch gefärbt ist, aber gerade auf der Uni Wien sind das ganze Studienzweige zu 100 \%." (Ausgeflippter Lodenfreak)

9 "Das hast sich einzig und alleine Aslan selbst zuzuschreiben. Wer sich in eine wissenschaftliche Studie von dahergelaufenen Ministerialbeamten hineinredigieren läßt, der hat kein Mitleid verdient. Wer sich mit Hunden ins Bett legt, der wird mit Flöhen wieder aufwachen." (Dr. Sheldon Lee Coper)

10 "Ob das Land ein Islamproblem hat, hat genau gar nichts damit zu tun, dass ein Mensch den Ruf der Wissenschaft durch seine Arbeitsweise in den Dreck zieht." (criticalvoice)

11 "Möchte Aslan insofern in Schutz nehmen, als daß er Religionspädagoge und nicht reiner Sozialwissenschafter ist. Dieser Methodenmix ist freilich schwerer zu handhaben." (witherabbitt)

Ahmed, S. and Matthes, J. (2017). 'Media representation of Muslims and Islam from 2000 to 2015: a meta-analysis'. International Communication Gazette 79 (3), pp. 219-244. https://doi.org/10.1177/1748048516656305.

Anderson, A. A., Brossard, D., Scheufele, D. A., Xenos, M. A. and Ladwig, P. (2014). "The "Nasty Effect": Online Incivility and Risk Perceptions of Emerging Technologies'. Journal of Computer-Mediated Communication 19 (3), pp. 373-387. https://doi.org/10.1111/jcc4.12009.

Bastow, S., Dunleavy, P. and Tinkler, J. (2014). The impact of the social sciences: how academics and their research make a difference. London, U.K.: Sage.

Bauer, M. W., Howard, S., Romo Ramos, Y. J., Massarani, L. and Amorim, L. (2013). Global science journalism report: working conditions $\mathcal{E}$ practices, professional ethos and future expectations. Our Learning Series. London, U.K.: Science and Development Network. URL: http://eprints.1se.ac.uk/48051/1/Bauer_Glob al_science_journalism_2013.pdf.

Berger, P. L. and Luckmann, T. (1966). The social Construction of reality: a treaties in the sociology of knowledge. Garden City, N.Y., U.S.A.: Doubleday.

Bogner, A. and Torgersen, H. (2005). 'Sozialwissenschaftliche Expertiseforschung. Zur Einleitung in ein expandierendes Forschungsfeld'. [Research on expertise in the social sciences. Introduction to an expanding research field]. In: Wozu Experten? Ambivalenzen der Beziehung von Wissenschaft und Politik. Ed. by A. Bogner and H. Torgersen. Wiesbaden, Germany: VS, pp. 7-29. 
Böhme-Dürr, K. (1992). 'Social and natural sciences in German periodicals'. Communications 17 (2), pp. 167-176.

https://doi.org/10.1515/comm.1992.17.2.167.

Bolsen, T., Druckman, J. and Cook, F. L. (2013). 'The effects of the politicization of science on public support for emergent technologies'. Working paper.

URL: https://www. ipr.northwestern.edu/publications/docs/workingpaper s/2013/IPR-WP-13-11.pdf.

Brantner, C. and Huber, B. (2013). 'How visible is communication studies? Press coverage of the discipline in three German-language quality newspapers'. Studies in Communication Media 2 (2), pp. 247-264. https://doi.org/10.5771/2192-4007-2013-2-247.

Burchell, K. (2009). 'A helping hand or a servant discipline?' Science, Technology $\mathcal{E}$ Innovation Studies 5, pp. 49-61. https://doi .org/10.17877/de290r-970.

Calvert, J. and Martin, P. (2009). 'The role of social scientists in synthetic biology'. EMBO reports 10 (3), pp. 201-204. https://doi .org/10.1038/embor. 2009.15.

Cassidy, A. (2008). 'Communicating the social sciences'. In: Handbook of Public Communication of Science and Technology. Ed. by M. Bucchi and B. Trench. London, U.K. and New York, U.S.A.: Routledge, pp. 225-236.

Coe, K., Kenski, K. and Rains, S. A. (2014). 'Online and uncivil? Patterns and determinants of incivility in newspaper website comments'. Journal of Communication 64 (4), pp. 658-679. https://doi .org/10.1111/jcom. 12104.

Declich, A. and d'Andrea, L. (2005). 'The sociological nature of science communication'. JCOM 04 (02), A02. https://doi .org/10.22323/2.04020202.

Döring, N. and Bortz, J. (2016). Forschungsmethoden und Evaluation in den Sozialund Humanwissenschaften. [Research methods and evaluation in the social sciences and humanities]. Berlin, Germany: Springer.

https://doi.org/10.1007/978-3-642-41089-5.

Fähnrich, B. and Lüthje, C. (2017). 'Roles of social scientists in crisis media reporting: the case of the German populist radical right movement PEGIDA'. Science Communication 39 (4), pp. 415-442. https://doi.org/10.1177/1075547017715472.

Felt, U. (2000). 'Die "unsichtbaren" Sozialwissenschaften: Zur Problematik der Positionierung sozialwissenschaftlichen Wissens im öffentlichen Raum'. [The "invisible" social sciences: difficulties of social sciences in positioning themselves in the public sphere]. In: Soziologische und historische Analysen der Sozialwissenschaften. Österreichische Zeitschrift für Soziologie Sonderband 5. Ed. by C. Fleck. Opladen and Wiesbaden, Germany: Westdeutscher Verlag, pp. $177-212$.

Foucault, M. (1988). Archäologie des Wissens. [Archeology of knowledge]. Frankfurt am Main, Germany: Suhrkamp.

Gerhards, J. and Neidhardt, F. (1991). 'Strukturen und Funktionen moderner Öffentlichkeit: Fragestellungen und Ansätze'. [Structures and functions of modern public sphere: questions and approaches]. In: Öffentlichkeit, Kultur, Massenkommunikation. Beiträge zur Medien- und Kommunikationssoziologie. [Public sphere, culture and mass communication. Contributions to sociology of media and communication]. Ed. by S. Müller-Doohm and K. Neumann-Braun. Oldenburg, Germany: Universitätsverlag, pp. 31-90. 
Gerhards, J. and Schäfer, M. S. (2010). 'Is the internet a better public sphere? Comparing old and new media in the USA and Germany'. New Media E Society 12 (1), pp. 143-160. https: //doi .org/10.1177/1461444809341444.

Göpfert, W. and Schanne, M. (1998). Das Förderprogramm Wissenschaftsjournalismus der Robert Bosch Stiftung GmbH. [Robert Bosch Foundations's funding program on science journalism]. Berlin, Germany and Zürich, Switzerland.

Habermas, J. (1992). Faktizität und Geltung. Beiträge zur Diskurstheorie des Rechts und des demokratischen Rechtsstaats. Frankfurt am Main, Germany: Suhrkamp.

Hsueh, M., Yogeeswaran, K. and Malinen, S. (2015). "'Leave your comment below": can biased online comments influence our own prejudicial attitudes and behaviors?' Human Communication Research 41 (4), pp. 557-576. https://doi.org/10.1111/hcre.12059.

Huber, B. (2014). Öffentliche Experten. Über die Medienpräsenz von Fachleuten. [Pundits in the news]. Wiesbaden, Germany: Springer VS.

Ibrahim, D. (2010). 'The framing of Islam on network news following the september 11th attacks'. International Communication Gazette 72 (1), pp. 111-125. https://doi.org/10.1177/1748048509350342.

IPSOS (2014). Public attitudes toward science. Main report.

URL: https://www.ipsos.com/sites/default/files/migrations/en-uk/file s/Assets/Docs/Polls/pas-2014-main-report.pdf.

Jung, C. (2009). 'Towards more confidence: about the roles of social scientists in participatory policy making'. Poiesis E Praxis 6 (1-2), pp. 125-129. https://doi.org/10.1007/s10202-008-0067-x.

Kaltenbrunner, A., Kraus, D., Leitner, J. and Zimmermann, A. (2006). Weiterbildung für Wissenschaftsjournalisten. Eine Studie des Medienhaus Wien. [Training for science journalists. A study of the Medienhaus Wien]. Wien, Austria: Medienhaus.

Keller, R. (2001). 'Wissenssoziologische Diskursanalyse'. [Sociology of knowledge approach to discourse]. In: Handbuch Sozialwissenschaftliche Diskursanalyse. [Handbook of social scientific discourse analysis]. Ed. by R. Keller,

A. Hirseland, W. Schneider and W. Viehöver. Wiesbaden, Germany: VS Verlag für Sozialwissenschaften, pp. 113-143.

- (2013). 'Zur Praxis der Wissenssoziologischen Diskursanalyse'. [The sociology of knowledge approach to discourse]. In: Methodologie und Praxis der Wissenssoziologischen Diskursanalyse. Band 1: Interdisziplinäre Perspektiven. Ed. by R. Keller and I. Truschkat. Wiesbaden, Germany: Springer VS, pp. 27-68.

Keller, R. (2005). 'Analysing discourse. An approach from the sociology of knowledge'. Forum Qualitative Sozialforschung / Forum: Qualitative Social Research 6 (3), Art. 32. https://doi.org/10.17169/fqs-6.3.19.

- (2011). 'The Sociology of Knowledge Approach to Discourse (SKAD)'. Human Studies 34 (1), pp. 43-65. https : //doi .org/10.1007/s10746-011-9175-z.

Knudsen, S. (2017). 'Thinking inside the frame: a framing analysis of the humanities in Danish print news media'. Public Understanding of Science 26 (8), pp. 908-924. https://doi.org/10.1177/0963662517693452.

LaBarre, S. (24th September 2013). 'Why we're shutting off our comments'. Popular Science. URL: https: //www . popsci.com/science/article/2013-09/why-wereshutting-our-comments. 
Lange, S. and Marquardt, W. (2014). 'Zum Spannungsverhältnis zwischen wissenschaftlicher Unabhängigkeit und Politikberatung'. [Tension between scientific independence and policy advice]. In: Politikberatung und Praxisgestaltung als Aufgabe der Wissenschaft?

Wissenschafts-Politik-Praxis-Kommunikation in der beruflichen Bildung. [Policy advice and implementation in practice as a task of science? Science policy practice communication in vocational education]. Ed. by F. H. Esser and Bundesinstitut für Berufsbildung (BIBB). Bielefeld, Germany: W. Bertelsmann Verlag, pp. 29-37. https://doi .org/10.3278/111-062w029.

Lee, E.-J. and Jang, Y. J. (2010). 'What do others' reactions to news on internet portal sites tell us? Effects of presentation format and readers' need for cognition on reality perception'. Communication Research 37 (6), pp. 825-846. https://doi.org/10.1177/0093650210376189.

Lörcher, I. and Taddicken, M. (2017). ‘Discussing climate change online. Topics and perceptions in online climate change communication in different online public arenas'. JCOM 16 (02), A03. https://doi .org/10.22323/2.16020203.

MA - Media Analyse (2017). Presse. [Press]. URL: https://www . media-analyse.at/table/2997.

Magin, M. and Stark, B. (2011). 'Österreich — Land ohne Leuchttürme? Qualitätszeitungen im Spannungsfeld zwischen publizistischer Leistung und strukturellen Zwängen'. [Austria - Country without lighthouses? Quality newspapers in tension between journalistic performance and structural constraints]. In: Krise der Leuchttürme öffentlicher Kommunikation Vergangenheit und Zukunft der Qualitätsmedien. [Crisis of the lighthouses of public discourse - past and future of quality media]. Ed. by R. Blum, K. Imhof and O. Jarren. Wiesbaden, Germany: VS Verlag für Sozialwissenschaften, pp. 97-114. https://doi.org/10.1007/978-3-531-93084-8_7.

Mishra, S. (2007). 'Saving Muslim women and fighting Muslim men: analysis of representations in the New York Times'. Global Media Journal 6 (11), pp. 1-20.

URL: http://www.globalmediajournal.com/open-access/saving-muslim-wom en-and-fighting-muslim-menanalysis-of-representations-in-the-new-yo rk-times . php?aid=35266.

Neidhardt, F. (1994). 'Öffentlichkeit, öffentliche Meinung, soziale Bewegungen'. [Public sphere, public opinion and social movements]. In: Öffentlichkeit, öffentliche Meinung, soziale Bewegungen. Ed. by F. Neidhardt. Wiesbaden, Germany: Westdeutscher Verlag, pp. 7-41.

Nowotny, H. (1975). 'Zur gesellschaftlichen Irrelevanz der Sozialwissenschaften'. [Public irrelevance of social sciences]. In: ed. by N. Stehr and R. König. Wiesbaden, Germay: VS Verlag für Sozialwissenschaften, pp. 445-456.

Pielke, R. A. (2004). 'When scientists politicize science: making sense of controversy over "The skeptical environmentalist"'. Environmental Science \& Policy 7 (5), pp. 405-417. https://doi.org/10.1016/j.envsci.2004.06.004.

Rowe, I. (2015). ‘Civility 2.0: a comparative analysis of incivility in online political discussion'. Information, Communication \& Society 18 (2), pp. 121-138. https://doi.org/10.1080/1369118x.2014.940365.

Santana, A. D. (2013). 'Virtuous or vitriolic. The effect of anonymity on civility in online newspaper reader comment boards'. Journalism Practice 8 (1), pp. 18-33. https://doi.org/10.1080/17512786.2013.813194. 
Saxer, U. (1997). 'Die prekäre Medienöffentlichkeit der Sozialwissenschaften'. [The precarious mass media public of social sciences]. Relation 4 (1), pp. 51-60.

Schäfer, M. S. (2012). 'Taking stock: A meta-analysis of studies on the media's coverage of science'. Public Understanding Science 21 (6), pp. 650-663. https://doi.org/10.1177/0963662510387559.

Schäfer, M. S., Füchslin, T., Metag, J., Kristiansen, S. and Rauchfleisch, A. (2018). 'The different audiences of science communication: a segmentation analysis of the Swiss population's perceptions of science and their information and media use patterns'. Public Understanding of Science 27 (7), pp. 836-856. https://doi.org/10.1177/0963662517752886.

Scheu, M. A. and Volpers, A.-M. (2017). 'Sozial- und Geisteswissenschaften im öffentlichen Diskurs'. [Social sciences and humanities in the public discourse]. In: Forschungsfeld Wissenschaftskommunikation. Ed. by H. Bonfadelli, B. Fähnrich, C. Lüthje, J. Milde, M. Rhomberg and M. S. Schäfer. Wiesbaden, Germany: Springer VS, pp. 391-404.

Schmidt, J.-H. (2013). ‘Onlinebasierte Öffentlichkeiten. Praktiken, Arenen und Strukturen'. [Online based public spheres. Practices, arenas and structures]. In: Online-Diskurse. [Online discourses]. Ed. by C. Fraas, S. Meier and C. Pentzold. Köln, Germany: Herbert von Halem Verlag, pp. 35-56.

Schummer, J. (2008). 'Science communication across disciplines'. In: Practising science communication in the information age. Ed. by R. Holliman, J. Thomas, S. Smidt, E. Scanlon and E. Whitelegg. Oxford, U.K.: Oxford University Press, pp. 53-66.

Science and Engineering Indicators (2014). Chapter 7. Science and technology: public attitudes and understanding. URL: https://www.nsf.gov/statistics/seind14/i ndex.cfm/chapter-7/c7h.htm.

Stehr, N. (1994). Arbeit, Eigentum und Wissen. Zur Theorie von Wissensgesellschaften. [Labour, property and knowledge. About theory of knowledge societies]. Frankfurt am Main, Germany: Suhrkamp Verlag.

Stehr, N. and Grundmann, R. (2010). Expertenwissen: Die Kultur und die Macht von Experten, Beratern und Ratgebern. [Expert knowledge. The culture and power of experts, advisors and consultants]. Weiland, Deutschland: Velbrück.

Stroud, N. J., Duyn, E. V. and Peacock, C. (2016). Engaging news project. URL: https://mediaengagement.org/wp-content/uploads/2016/03/ENP-News -Commenters-and-Comment-Readers1.pdf.

Su, L. Y.-F., Xenos, M. A., Rose, K. M., Wirz, C., Scheufele, D. A. and Brossard, D. (2018). 'Uncivil and personal? Comparing patterns of incivility in comments on the Facebook pages of news outlets'. New Media \& Society 20 (10), pp. 3678-3699. https://doi.org/10.1177/1461444818757205.

Sugiura, L., Wiles, R. and Pope, C. (2017). 'Ethical challenges in online research: public/private perceptions'. Research Ethics 13 (3-4), pp. 184-199. https://doi.org/10.1177/1747016116650720.

Šuljok, A. and Vuković, M. B. (2013). 'How the Croatian daily press presents science news'. Science and Technology Studies 26 (1), pp. 92-112.

URL: https://sciencetechnologystudies . journal.fi/article/view/55310.

Summ, A. and Volpers, A.-M. (2016). 'What's science? Where's science? Science journalism in German print media'. Public Understanding of Science 25 (7), pp. 775-790. https://doi.org/10.1177/0963662515583419. 
Vestergård, G. L. and Nielsen, K. H. (2017). 'From the preserves of the educated elite to virtually everywhere: a content analysis of Danish science news in 1999 and 2012'. Public Understanding of Science 26 (2), pp. 220-234. https://doi.org/10.1177/0963662515603272.

Vestergård, G. L. and Nielsen, K. H. (2016). 'Science news in a closed and an open media market: a comparative content analysis of print and online science news in Denmark and the United Kingdom'. European Journal of Communication 31 (6), pp. 661-677. https://doi.org/10.1177/0267323116674110.

von Sikorski, C. and Hänelt, M. (2016). 'Scandal 2.0. How valenced reader comments affect recipients' perception of scandalized individuals and the journalistic quality of online news'. Journalism $\mathcal{E}$ Mass Communication Quarterly 93 (3), pp. 551-571. https: //doi .org/10.1177/1077699016628822.

Wilkinson, C. (2014). 'Engaging with strangers and brief encounters: social scientists and emergent public engagement with science and technology'. Bulletin of Science, Technology \& Society 34 (3-4), pp. 63-76. https://doi.org/10.1177/0270467614552841.

Wissenschaftsbarometer - Wissenschaft im Dialog (2017). Wie groß ist Ihr Interesse an wissenschaftlichen Themen aus den Bereichen...?

URL: https://www.wissenschaft-im-dialog.de/fileadmin/user_upload/Pro jekte/Wissenschaftsbarometer/Dokumente_17/Einzelgrafiken/02_WB_17_Ei nzelgrafik_2_Interesse_wissenschaftliche_Disziplinen.png.

Wissenschaftsbarometer Schweiz (2016). Tabellenband. Switzerland.

URL: http://www.wissenschaftsbarometer.ch/wp-content/uploads/2016/11 /WissensCHaftsbarometer_2016_Tabellenband_DE.pdf.

Authors

Brigitte Huber is a Post Doc at the Department of Communication at the University of Vienna. She finished her Ph.D. at the University of Vienna in 2013, worked as a Post Doc at the Department of Communication Science and Media Research at the Ludwig Maximilian University of Munich for a year, and came back to the University of Vienna to join the Media Innovation Lab in 2014. Her research interests include science communication, political communication, journalism studies, and social media. E-mail: brigitte.huber@univie.ac.at.

Irmgard Wetzstein is a Senior Lecturer at the Department of Communication at the University of Vienna's Faculty of Social Sciences, former Fulbright Visiting Professor at the University of Minnesota's School of Journalism and Mass Communication, and trained mediator. She received her Ph.D. in media communications in 2010 and has been working in social research and teaching since 2006, focusing on social media and ICTs, strategic communication, visual communication, journalism, conflict communication, advertising research, gender media studies, and migration. E-mail: irmgard.wetzstein@univie.ac.at. 
Ingrid Aichberger is a Senior Scientist at the Department of Communication Studies at the University of Salzburg. She received her master in communication sciences at the University of Vienna in 2009 and worked as a research assistent in several research projects for university and non-university research institutions in Austria. Her current research interests lie in the field of science communication, social media, journalism studies, and mediatization research.

E-mail: Ingrid.Aichberger@sbg.ac.at.

How to cite

Huber, B., Wetzstein, I. and Aichberger, I. (2019). 'Societal problem solver or deficient discipline? The debate about social science in the online public sphere'. JCOM 18 (02), A04. https:/ / doi.org/10.22323/2.18020204. 